\title{
MORPHOLOGY OF THE TESTICLES OF SOME BRAZILIAN SPECIES OF DIPLOPODA AND THEIR PHYLLOGENETIC RELATIONS
}

\author{
Carmem Silvia Fontanetti ${ }^{1}$
}

\begin{abstract}
The morphology of the testicles of some Brazilian species of Diplopoda is described. One type is scalariform, with two deferent ducts and the other consists of some single deferent duct. Phyllogenetic considerations on the structure are made.
\end{abstract}

\section{INTRODUCTION}

Papers on the male reproductive system of diplopods are rare and most of them not recent. The first papers on the male reproductive system of millipedes were those of TREVIRANUS 1817 apud NEWPORT, 1841), NEWPORT (1841), FABRE (1855) and ATTEMS (1894), but these observations are superficial in regard to the internal part of the system since they deal mainly with the description of the gonopods for taxonomic use.

Other papers were published on polydesmid millipedes (MILEY, 1927; 1930; SEIFERT, 1932; WARREN, 1934). WARREN, studying five species, found three type of reproductive system: the reticular, scalariform and the one with two deferent ducts without the connection tubes, named arthrosphaeroid.

WEST (1953) studied Scytonotus virginicus (Polydesmidae) mentioning the internal anatomy of the reproductive apparatus and the testicle cycle. In 1974, KANAKA \& CHOWDAIAH analyzed the morphology of the testicles of six species (comprising three families) of Indian diplopods, subdividing them in several types; phyllogenetic considerations about them were made. In the same year (1974), PETIT published a study about the spermatogenesis of Polydesmus angustus.

The most recent papers are those of CECCHI \& CHELAZZI (1984), on a Spirobolida and FONTANETTI (1988), on three Brazilian species pertaining to Spirobolida, Polydesmida and Spirostreptida orders. In this last paper, the author describes the internal structures of the testicles. The major focus is, however, the histology of the structure and testicle cycle. In the present paper the author shows the morphology of the testicles of some species of Diplopoda, trying to relate these observations to those of other authors. The evolution of the gonads' morphology is speculated.

1. Depto. de Biologia - Instituto de Biociências - UNESP - Campus de Rio Claro - Caixa Postal 178 - CEP 13500 - Rio Claro - São Paulo. 
Revta bras. Zool.

\section{MATERIAL AND METHODS}

Adult males of 17 species of Brazilian diplopods, comprising 9 genera and 5 families were used. The specimens were collected in the nature in different periods of the year and localities; the species were:

Order Polydesmida

Family Chelodesmidae

Leptodesmus dentellus Schubart - Rio Claro, São Paulo.

Sandalodesmus sp - 34 km NE from Dourados, Mato Grosso do Sul. .

Brasilodesmus nudipes (Attems) - Biological Station of Boracéia, São Paulo.

Order Spirostreptida

Family Spirostreptidae

Plusioporus setiger (Brolemann) - Rio Claro, São Paulo.

Alloporus principes Brolemann - Scrub of Corumbataí, São Paulo.

Gymnostreptus olivaceus Schubart - Rio Claro, São Paulo.

Gymnostreptus acuticollis Verhoeff - Biological Station of Boracéia, São Paulo.

Urostreptus sp - Rio Claro, São Paulo.

Family Psęudonannolenidae

Pseudonannolene sp - Toca Cave, $10 \mathrm{~km}$ from Itirapina, São Paulo

Pseudonannolene tricolor Brolemann - Rio Claro, São Paulo

Pseudonannolene ophiulus Schubart - Barreiro Rico Farm, São Paulo

Pseudonannolene halophila Schubart - Alcatrazes Islands, São Paulo

Pseudonannolene strinatii Mauriès - Ressurgência das Areias Cave, Iporanga, São Paulo

Order Spirobolida

Family Rhinocricidae

Rhinocricus padbergi Verhoeff - Rio Claro, São Paulo

Rhinocricus cachoeirensis Schubart - Scrub of Corumbataí, São Paulo

Rhinocricus sp - $16 \mathrm{~km} \mathrm{~N}$ from Jacupiranga, São Paulo

\section{RESULTS AND DISCUSSION}

Two different morphological types of testicles can be observed in the species studied as seen in figure 1. Type A is scalariform consisting of two deferent ducts (dd) running parallel and longitudinally. Several rounded testicles vesicles ( $t$ ) are connected of them. The deferent ducts are united by small tubes called tubes of connexion of the deferent ducts (tc). This type was observed in species of the families: Chelodesmidae (Leptodesmus dentellus, Sandalodesmus sp, Brasilodesmus nudipes), Paradoxomatidae (Asiomorpha coarctata) and Spirostreptidae (Plusioporus setiger, Alloporus principes, Gymnostreptus olivaceus, G. acuticollis, Urostreptus sp). Type B consists of a large deferent duct (dd), where numerous reniform testicle vesicles $(t)$ are attached by a pedicle (p). The families Pseudonannolenidae (Pseudonannolene sp, $P$. strinatii, $P$. halophila, $P$. ophiulus) and Rhinocricidae (Rhinocricus sp, $R$. padbergi, $R$. cachoeirensis) show this morphology.

Type A might be the most common in the group since it has been described in a large number of species: Iulus terrestris (NEWPORT, 1841), I. aterrinus, Polydesmus complanatus (FABRE, 1855), Euryurus erythropygus (MILEY, 1930), Strongylogsoma pallipes (SEIFERT, 1932), Chersastus ruber, Ulodesmus bispinosus (WARREN, 1934), 
Schizophyllum sabulosum (BESSIÈRE, 1948), Scytonotus virginicus (WEST, 1953), Ktenostreptus costulatus, Aulacobolus variolosus, A. levissimus (KANAKA \& CHOW. DAIAH, 1974), Polydesmus angustuis (PETIT, 1974), Epibolus pulchripes bravensis (CECCHI \& CHELAZZI, 1984) and Leptodesmus dentellus (FONTANETTI, 1988). According to WEST (1953) and KANAKA \& CHOWDAIAH (1974) this is the basic model found in Diplopoda.
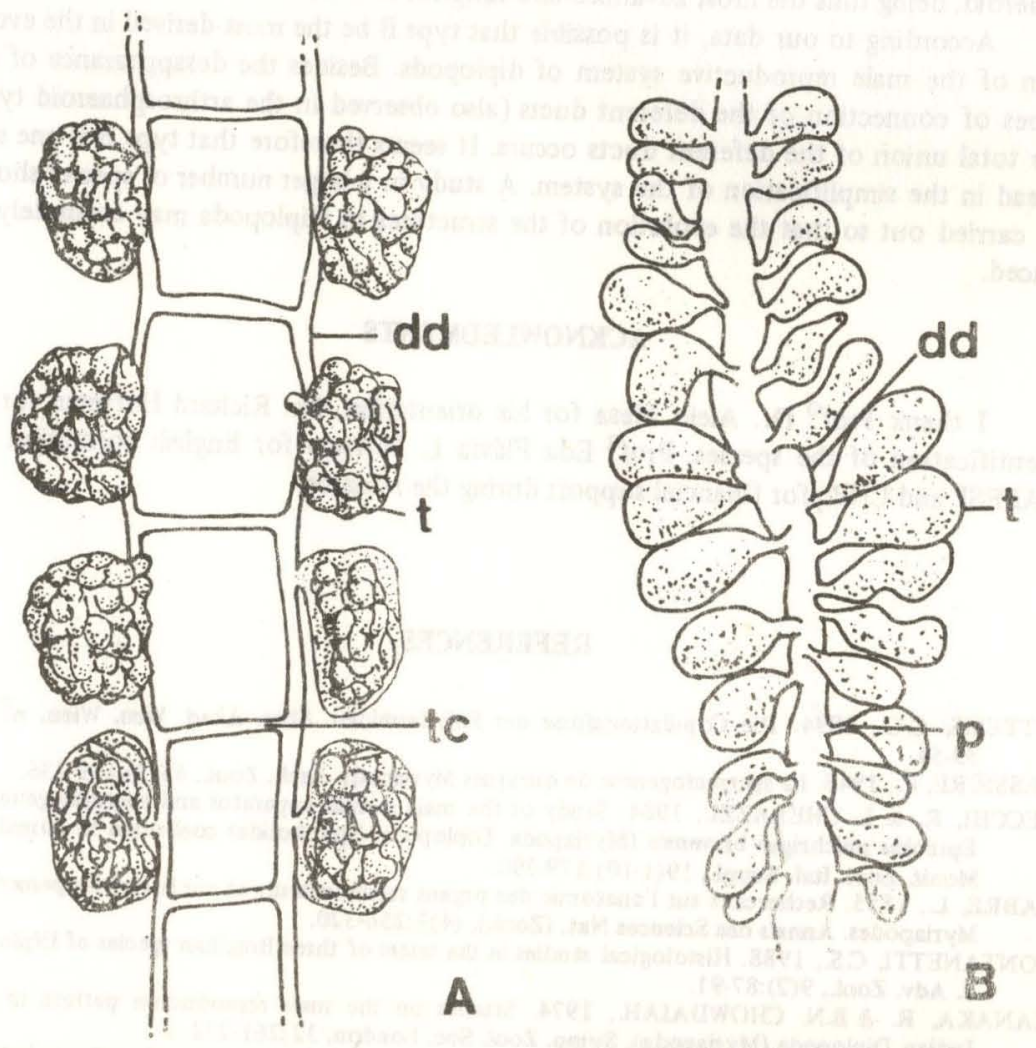

Figura 1: Schemata of the two types of reproductive system found in Brazilian diplopods. A, Scalariform type $(\mathrm{dd}=$ deferent duct; $\mathrm{t}=$ testicle vesicle; $\mathrm{tc}=$ tubes of connexion of the deferent ducts). B. Type consisted of a deferent duct (dd) where several testicle vesicles ( $t$ ) are connected through a pedicle $(\mathrm{p})$.

The descriptions that most resemble the type B described by FONTANETTI (1988), for Pseudonannolene sp and Rhinocricus padbengi, are those of FABRE (1855) for Polyxenus lagurus and Glomeris marginata and BESSIEERE (1948) for Glomeris annulata.

KANAKA \& CHOWDAIAH in 1974 studying six species from the Southern region of India, Spirostreptus asthenes, Harpurostreptus robustior, Ktennsteptus costalatus, Aulacobohus variolosus, A. levissimus and Arthrosphaera craspedota, also found the three types of reproductive system mentioned by WARREN in 1934: the reticular, the 
scalariform and the arthrosphaeroid type. The reticular type shows the deferent ducts in the shape of a reticle. The arthrosphaeroid type shows some transversal connexions only in anterior part, being the two parallel ducts independent in the region where the testicles vesicles are connected. KANAKA \& CHOWDAIAH (1974) suggested that the most primitive and complex reproductive system in Diplopoda is the reticulate one from which, during the course of evolution, derived the scalariform and from this the arthrosphaeroid, being thus the most advanced and simplest of them all.

According to our data, it is possible that type B be the most derived in the evolution of the male reproductive system of diplopods. Besides the desappearance of the tubes of connection of the deferent ducts (also observed in the arthrosphaeroid type) the total union of the deferent ducts occurs. It seems therefore that type B is one step ahead in the simplification of the system. A study in a larger number of species should be carried out so that the evolution of the structures in Diplopoda may accurately be traced.

\section{ACKNOWLEDMENTS}

I thank Prof? Dr. Alejo Mesa for his orientation, Dr. Richard Hoffman for the identification of the species, Prof. Eda Flávia L. Patrício for English correction and FAPESP and $\mathrm{CNPq}$ for financial support during the research.

\section{REFERENCES}

ATTEMS, C.G., 1894. Die Copulationsfusse der Polydesmiden. Sber. Akad. Wiss. Wien, no 103: 39-54.

BESSIERE, C., 1948. La spermatogenèse de quelques Myriapods. Arch. Zool., 85(3):149-236.

CECCHI, R \& L CHELAZZI., 1984. Study of the male genital apparatus and spermatogenesis in Epibolus pulchripes bravensis (Myriapoda, Diplopoda, Spirobolida) coellected in Somaliland. Monit. Zool. Ital. Suppl., 19(1-10):179-290.

FABRE, L, 1855. Recherches sur l'anatomie des organs reproducteurs et sur le developpement des Myriapodes. Annals des Sciences Nat. (Zool.), (4)3:256-320.

FONTANETTI, C.S., 1988. Histological studies in the testes of three Brazilian species of Diplopoda. J. Adv. Zool., 9(2):87-91.

KANAKA, R. \& B.N. CHOWDAIAH, 1974. Studies on the male reproductive pattern in some Indian Diplopoda (Myriapoda). Symp. Zool. Soc. London, 32:261-272.

MLEY, H.H., 1927. Development to the male gonopods and life history studies of a polydesmid millipede. Ohio J. Sci., 27:25-43.

MILEY, H.H., 1930. Internal anatomy of Euryurus ery thropygus (Brandt) (Diplopoda). Ohio J. Sci., 30(4):229-254.

NEWPORT, G., 1841 . On the organs of reproduction and the development of the Myriapoda. Philos. Trans. Royal Soc. Londun, 99-130.

PETIT, J., 1974. Contribution à l'étude de l'appareil genital mâle et de la spermatogenèse chez Polydesmus angustus Latzel, Myriapode, Diplopode. Symp. Zool. Soc. London, 32:249-259.

SEIFERT, B., 1932. Anatomie und Biologie des Diplopoden Strongylosoma pallipes Oliv. Zeits. Morph. und Okol. Tiere, 25:362-507.

WARREN, E., 1934. On the male genital, system and spermatozoa of certain millipedes. Ann. Natal. Mus. P'mburg, 7(3):351-402.

WEST, W.R., 1953. An anatomical study of the male reproductive system of a Virginia millipede. J. Morph., 93(1):123-176. 